\title{
Zencefil ve Keten Tohumu Oleoresinlerinin Elde Edilmesi ve Ekstraksiyon Koşullarının Cevap Yüzey Yöntemi İle Optimizasyonu
}

\author{
Büşra Şahin ${ }^{1}$, Seda Özgen ${ }^{1 *}$ \\ ${ }^{1}$ Çankırı Karatekin Üniversitesi, Mühendislik Fakültesi, Gıda Mühendisliği Bölümü, Çankırı, Türkiye (ORCHID:0000-0001-5019-6898), busra1894@hotmail.com \\ ${ }^{1 *}$ Çankırı Karatekin Üniversitesi, Mühendislik Fakültesi, Gıda Mühendisliği Bölümü, Çankırı, Türkiye (ORCHID:0000-0001-9952-5015), sozgen@karatekin.edu.tr
}

(İlk Geliş Tarihi 20 Nisan 2020 ve Kabul Tarihi 10 Kasım 2020)

(DOI: $10.31590 /$ ejosat.724113)

ATIF/REFERENCE: Şahin, B. \& Ozgen, S., (2020). Zencefil Ve Keten Tohumu Oleoresinlerinin Elde Edilmesi Ve Ekstraksiyon Koşullarının Cevap Yüzey Yöntemi İle Optimizasyonu. Avrupa Bilim ve Teknoloji Dergisi, (20), 602-613.

Öz

Günümüzde; hastalıkların önlenmesinde ve tedavisinde doğal yollarla alınan birtakım gıdaların etkili olduğunun bilimsel olarak ispatlanması, tüketicilerin bu gıdalara olan ilgisini ve bu gıdaların önemini arttırmıştır. Yapılan bilimsel çalışmaların sonuçları tüketicileri beslenme alışkanlıkları üzerinde düşünmeye ve düzenleme yapmaya itmiş ve yaygın olarak kullanılan sentetik katkı maddeleri hakkındaki düşüncelerini olumsuz etkileyerek doğal bitkisel kaynaklara yönlendirmiştir. Bu gelişmelerle birlikte, bitkilerden doğal antioksidanların elde edilip, geliştirilip ve çeşitlendirilmesi üzerine yapılan araştırmalar da hız kazanarak devam etmiş ve tıbbi ve aromatik bitkiler ile baharatlar, araştırmaların odak noktası haline gelmiştir. Sıvı baharat olarak bilinen oleoresinler, sahip oldukları fizyolojik aktiviteleri sayesinde, bazı tip kanserleri, kardiyovasküler hastalıkları ve yaşlanmayı önleyici etki göstermekte, bağışıklık sistemini güçlendirmekte, kolesterolü, tansiyonu ve kan şekerini düşürücü etki göstermektedir. Yapılan çalışmada ham ürüne göre üstünlükleri olan, fenolik ve yă̆ asitlerince konsantre edilmiş formda, hem gıda katkıları hem de fonksiyonel ürün olarak çeşitli amaçlarla kullanımları mümkün olan keten tohumu ve zencefil oleoresinleri elde edilmiş ve elde edilmesinde kullanılan solvent ekstraksiyonu koşulları optimize edilmiştir. Bu amaçla deney paremetrelerine göre üç faktör-üç seviye Box-Behnken tepki yüzey deneme deseni oluşturularak ekstraksiyon işlemi gerçekleştirilmiştir. Ekstraksiyon sıcaklığı, ekstraksiyon süresi ve örnek/çözücü oranı değişken parametre olarak belirlenmiştir. Bu değişken parametrelerin ekstraksiyon verimi, toplam fenolik madde miktarı ve radikal süpürücü güçleri üzerine etkisi incelenmiştir. Bu etkilerin değerlendirilmesinde ise; DesignExpert $^{\circledR}$ yazılım programı kullanılmıştır. Zencefilden toplam fenolik miktarı, antiradikal aktivitesi ve ekstraksiyon verimi yüksek olan oleoresin elde edilmesinde; örnek çözücü oranı $1 / 40$, sıcaklık $42,5^{\circ} \mathrm{C}$ ve ekstraksiyon süresi 22 dakika olarak optimize edilmiştir. Keten tohumundan elde edilen oleoresin için program cevaplarının maksimum değerde olduğu koşullar; örnek çözücü oranı 1/35, sicaklık $41,3^{\circ} \mathrm{C}$ ve ekstraksiyon süresi 27 dakika olarak optimize edilmiştir.

Anahtar Kelimeler: Oleoresin, Zencefil, Keten Tohumu, Cevap Yüzey Yöntemi.

\section{Isolation of Ginger and Flaxseed Oleoresins and Optimization of Extraction Conditions by Response Surface Methodology}

\begin{abstract}
Today, scientific proof that certain foods taken by natural means are effective in the prevention and treatment of diseases has increased consumers ' interest in these foods and the importance of these foods. The results of scientific studies have led consumers to think about and regulate their eating habits and directed them to natural herbal sources that have negatively affected their thinking about widely used synthetic additives. With these developments, research on the acquisition, development and diversification of natural antioxidants from plants continued to increase, and medicinal and aromatic plants and spices became the focus of research. Oleoresins, known as liquid spices, have physiological activities that prevent certain types of cancers, cardiovascular diseases and aging, strengthen the immune system, cholesterol, blood pressure and blood sugar lowering effect. In the study, linseed and ginger oleoresins, which are superior to raw products, are obtained in phenolic and fatty acids concentrated form, which can be used for various purposes as both food additives and functional products, and the solvent extraction conditions used in their production were optimized. For this purpose, Three Factor-three Level Box-Behnken surface test pattern was created according to the test parameters and extraction process was performed. Extraction temperature, extraction time and sample/solvent ratio were determined as variable
\end{abstract}

${ }^{*}$ Sorumlu Yazar: ${ }^{1 *}$ Çankırı Karatekin Üniversitesi, Mühendislik Fakültesi, Gıda Mühendisliği Bölümü, Çankırı, Türkiye (ORCHID:0000-0001-9952-5015), sozgen@karatekin.edu.tr 
parameters. The effect of these variable parameters on extraction yield, total amount of phenolic and radical scavenger powers were studied. In the evaluation of these effects; Design-Expert ${ }^{\circledR}$ software program was used. The total phenolic content, antiradical activity and extraction yield of flax seed were optimized for high oleoresin; sample solvent ratio was $1 / 35$, temperature $41.3^{\circ} \mathrm{C}$ and extraction time was also 27 minutes. In ginger, the conditions in which the program responses are maximum are optimized; sample solvent ratio is $1 / 40$ temperature $42.5^{\circ} \mathrm{C}$ and extraction time is 22 minutes.

Keywords: Oleoresin, Ginger, Flax Seed, Response Surface Methodology.

\section{Giriş}

Bitki ve baharatlardan; kendine özgü tat ve aromaları, antioksidan ve antimikrobiyal özellikleri nedeniyle geniş biyoaktif etkinliğe sahip olan sarımsak, kekik, kırmızıbiber, zencefil, keten tohumu gibi ürünler gıda endüstrisinde biyo-fonksiyonel ürünlerin üretiminde kullanılan hammaddelerdendir. Bu gibi terapötik özellik gösteren birçok bitki ve baharat türünden eski çağlardan beri halk ilacı olarak çeşitli hastalıkların tedavisinde yararlanılmıştır. Günümüzde ise bu bitki ve baharatlar tıp, eczacılık, gıda endüstrisi ve kozmetik sektöründe sıklıkla kullanılmaktadır.

Zencefil, karakteristik tat ve keskin aroması nedeniyle, dünya çapında baharat ve gıda katkı maddesi olarak kullanılmaktadır. Zencefil ayrıca güçlü bir antioksidan madde olup, serbest radikallerin oluşumunu azaltıp önleyebilir özelliktedir. Bu nedenle, tıbbi değeri giderek artmaktadır. Zencefilde bulunan en önemli aktif maddeler 6-gingerol ve 6-paradol bileşimleridir (Yeh ve ark., 2014; Zancan ve ark., 2002). Keten (Linum usitatissimum), ve tohumları çok eski dönemlerden beri çeşitli amaçlar ile kullanılmaktadır. Tarihte Romalılar, Yunanlılar ve Mısırlılar keten tohumunu sindirim sistemi ve bazı hastalıkların tedavisi için kullanmışlardır. Bu zamana kadar ekmek, makarna, kekler, bageller, kurabiye ve kek gibi çeşitli hububat bazlı ürünlerin kalitesini arttırmak için kullanılmıştır (Hao ve Beta, 2012; Kajla ve ark., 2015; Mercier ve ark., 2015).

Serbest radikallerin biyomoleküllere oksidatif hasar verdiğine ve kardiyovasküler hastalık, yaşlanma, kanser, enflamatuar hastalıklar ve diğer çeşitli bozukluklarda önemli bir rol oynadığına dair önemli kanıtlar vardır (Noguchi ve Nikki, 2000). Serbest radikalleri temizleyen moleküllerin artık serbest radikal aracılı hastalık koşullarında önleyici ve terapötik potansiyele sahip olduğu bilinmektedir (Visioli ve ark., 2001). Zencefilin ve keten tohumunun antioksidan etkisi, toksisiteye karşı koruyucu eylemler için olası en önemli mekanizmalara örnek olarak önerilmiştir. Son zamanlarda, bu kaynaklardaki aktif bileşenlerin güçlü anti-enflamatuar ve anti-apoptotik etkilere ek olarak hem in vivo hem de in vitro güçlü antioksidan etki ile donatıldığı gösterilmiştir (Maizura ve ark., 2011; Scalbert ve ark., 2005).

Oleoresinler, kurutulan veya ögütülen baharatın uygun bir organik çözücü yardımıyla ekstrakte edilmesi ve sonrasında çözücünün uzaklaştırılması ile elde edilen sıvı baharatlardır. Son derece yoğun, viskoziteleri yüksek olan oleoresinler reçinemsi yapıda ve koyu renklidirler. Oleoresinleri "yağ-reçine karışımı”, "sıvı baharat”, "baharat damlası” olarak tanımlamak da mümkündür. Reçine kavramı, baharatın uçucu yağ dışında kalan ve ekstrakte edilebilen tüm bileşenlerini kapsamaktadır. Oleoresin eldesinde uygun çözücü seçimi oldukça önemlidir. Oleoresinler yüksek kaynama noktalı ve uçucu olmayan bileşenler de içerdiği için esansiyel yağlardan ayrılmaktadırlar (Küçüközet ve Uslu 2018). Gerçek baharat özlerinin konsantre formundan oluşan oleoresinler, uçucu bileşiklerin yanı sıra uçucu olmayan bileşikler de içermektedir. Uçucu olmayan bileşikler izole edildiğinde karatenoid, steroid, alkoloid, antosiyanin, glikozid gibi farklı kimyasal bileşenler de oleoresin içinde yer almaktadır. Bu farklı fraksiyonlarda ürünün antioksidan özelliği ve biyoaktivitesine katkıda bulunmaktadır. Dolayısıyla oleoresinler bir baharatın tüm lezzet özelliklerini taşıdı̆̆ı için baharat esansiyel yağlarına ve toz baharatlara göre daha avantajlı kullanım alanı sağlamaktadır (Ponce ve ark., 2008). Özellikle solvent ektraksiyonu ile elde edilen oleoresinler, taze baharatlara daha yakın özellikler göstermektedirler. Bu durum oleoresini, gıda endüstrisinde kullanılmak üzere en uygun ve doğal katkı maddesi yapmaktadır. Ayrıca son üründe daha iyi bir dağılım sağlar ve daha az depolama alanı gerektirir (Shaikh ve ark., 2006; Kanakdande ve ark., 2007; Küçüközet and Uslu 2018).

Ceviz yeşil kabuğundan ultrases yardımıyla fenolik madde ekstraksiyonunda optimizasyon yapılmış, ekstraksiyon koşulları etanol konsantrasyonu, sıcaklık ve ultrases genliği olarak; belirlenmiştir (Sarıtaş, 2018). Araştırıcılar, keten tohumu yağını, süperkritik karbondioksit ekstraksiyonu ile ekstre etmiş ve ekstraksiyon kinetiği difüzyon kontrol yöntemi ile modellemiştir (Hoşgün, 2013). Ekstraksiyon verimi (\%) üzerine en fazla sırasıyla basınç, akış hızı ve sıcaklık etki etmiştir. Bir diğer çalışmada Dulavratotunun (Arctium lappa L.), mikrodalga destekli ekstraksiyonunda optimum çalışma koşulları, cevap yüzey metodolojisi kullanılarak belirlenmiştir. Toplam antioksidan kapasite ve toplam fenolik içeriği üzerine ekstraksiyon sıcaklığının tüm operasyonel parametreleri arasında en önemli faktör olduğu bulunmuştur (Bekdeşer 2017). Geleneksel yöntemler (Eliasson ve ark, 2003; Johnsson ve ark, 2000), mikrodalga destekli ekstraksiyon (Fliniaux ve ark, 2014; Beejmohun ve ark, 2007; Zhang ve ark, 2009), veya enzimatik destekli ekstraksiyon (Milder ve ark, 2004; Renouard ve ark, 2010) kullanılarak değerli keten tohumu bileşiklerinin ekstraksiyonunu ve analizini optimize etmek için çeşitli çalışmalar yapılmıştır. Yine birçok çalışma da (Chan ve ark 2007; Ding ve ark., 2012; Yeh ve ark., 2014) kullanılan ekstraksiyon yöntemi ve çözücünün; zencefilde ekstrakt kalitesini, antioksidan aktivite ve toplam fenolik içeriklerini değiştirebileceği gösterilmiştir.

Günümüzde çeşitli proseslerde en yüksek verimin en ekonomik şekilde elde edildiği koşulların belirlenmesi için yapılan optimizasyon yöntemleri bilimsel çalışmalar ve mühendislik problemlerinin çözümünde araştırıcılar tarafından yaygın olarak kullanılmaya başlanmıştır. Matematiksel modellerin ve istatistiksel analiz yöntemlerinin birlikte kullanıldığg bu modelleme teknikleri ile, yapılan deney sayıları azaltılmakta ve proseslerin kontrolü de kolay olmaktadır. Tepki Yüzey Metodu (Response Surface Methodolgy, RSM) ile araştırmacılar tüm denemeyi temsil edecek biçimde daha az deneme ünitesi ile daha hızlı bir biçimde sonuca ulaşabilmektedirler. Tepki yüzeyi metodu proses girdileri ile çıktıları arasındaki ilişkileri matematiksel modeller ile ortaya koymaktadır (Montgomery, 2001).

Her ne kadar zencefil ve keten tohumu ile ilgili çalışmalar olsa da, zencefil ve keten tohumu oleoresinlerinin ekstraksiyonu, ekstraksiyon koşullarının belirlenmesi ve ekstrakte edilen bu oleoresinlerin biyolojik aktivitesinin araştırıldığı çalışmalara ihtiyaç duyulmaktadır. İçerisinde yeni teknolojilerin de bulunduğu biyoaktif bileşiklerin ekstraksiyonu ile ilgili araştırmalar da giderek artmaktadır. Bu çalışmanın amacı ise, keten tohumu ve zencefilden yüksek biyoaktiviteye sahip oleoresinlerin ekstraksiyonu için 
uygun koşulları tepki yüzey metodu kullanarak belirlemektir. Bu kapsamda DESIGN EXPERT v.11.0 yazılımı deneme sürümü kullanılmıştır. Deney paremetrelerine göre de üç faktör-üç seviye Box-Behnken tepki yüzey deneme deseni oluşturularak ekstraksiyon işlemi gerçekleştirilmiştir. Çalışmanın ekstraksiyon aşamasında ekstraksiyon sıcaklığı, ekstraksiyon süresi ve örnek/çözücü oranı değişken parametre olarak belirlenmiş̧tir ve bu değişken parametrelerin ekstraksiyon verimi, toplam fenolik madde miktarı ve radikal süpürücü güçleri üzerine etkisi incelenmiştir ve ekstraksiyon işlemi optimize edilmiştir.

\section{Materyal ve Metot}

\subsection{Materyal}

Yapılan araştırmada bitkisel hammadde kaynağı olarak yerel piyasadan temin edilen zencefil ve keten tohumu kullanılmıştır. Yapılan literatür incelemelerine dayanarak hammadde kaynağı taze zencefilin dondurularak kurutulması planlanmıştır (Guinea ve ark., 2012). Taze olarak temin edilen ve ortalama \% 90 nem içeriğine sahip zencefil küçük parçalar halinde liyofilizatörde (Labconco Freezone 2.5 , Amerika) $-52{ }^{\circ} \mathrm{C}$ 'de vakum altında dondurularak kurutulmuştur. Keten tohumu ise kuru halde satın alınmıştır. Sabit tartıma gelip gelmediği test eilmiştir. Kullanılacak olan hammaddeler öğütülerek, $+4^{\circ} \mathrm{C}$ 'de analiz edilinceye kadar depolanmıştır. Kullanılan tüm kimyasallar, reaktifler ve solventler ise analitik saflıkta olup Merck, Sigma ve Carlo Erba firmalarından temin edilmiştir.

\subsection{Yöntem}

\subsubsection{Ekstraksiyon İşlemi ve Ekstraksiyon Koşullarının Optimizasyonu}

Sunulan çalışmada organik çözücülerle yapılan ekstraksiyon yönteminde 2013/45 tarihli 28739 numaralı resmi gazetede yayınlanan 'Türk Gıda Kodeksi Gıda Maddelerinin ve Gıda Bileşenlerinin Üretiminde Kullanılan Ekstraksiyon Çözücüleri Tebliği'ne göre seçilen ve gıdalarda kullanılmasına izin verilen organik çözücüler kullanılmıştır. Yapılan literatür incelemesine de dayanarak kurutulan zencefil ve keten tohumu oleoresinlerinin elde edilmesinde çözgen olarak etanol, aseton ve etil asetat kullanılmış ve yapılan ön denemeler ile kullanılacak çözgen ve oranları belirlenmiştir.

Bir bileşiğin ekstraksiyonu bitki materyalinin doğrudan ekstraksiyon çözücüsü ile polarite eşleşmesi ile ilgilidir. Ön denemelerde elde edilen ekstraksiyon verimi ve oleoresinin radikal süpürücü gücü göz önüne alındığında; zencefil oleoresinlerinin eldesi için; sırasıyla \%40-\%40-\%20; etanol, etil asetat ve aseton karışımının, keten tohumu oleoresinleri eldesi için ise; \%50 etanol-etil asetat karışımı organik çözücü olarak kullanılmıştır. Öğütülen örnekler farklı oranlarda (mL solvent/g bitki) solvent ile karıştırılmış ve farklı sıcaklık ve sürelerde ekstraksiyona tabi tutularak ekstraksiyon koşulları optimize edilmiştir. Ekstraksiyon süresi sonunda örnekler önce santrifüj (5000 rpm'de 10 dakika) sonra da filtre edilerek ekstraktlar elde edilmiş, solvent karışımı rotary evaporatörde uzaklaş̧ırılmış ve elde edilen oleoresinler $-18^{\circ} \mathrm{C}$ 'de muhafaza edilmişsir.

\subsubsection{Deneysel Tasarım ve Cevap Yüzey Metodu (Response Surface Methodology-RSM) ile Ekstraksiyon Koşullarının Optimizasyonu}

Keten Tohumu ve zencefil oleoresinlerinin ekstraksiyonunda bağımsız değişkenler için belirlenen değer aralıklarının seçiminde örnek/çözücü oranı, sıcaklık ve süre optimize edilmiştir.

Deneme tasarımı seçerken ya 1. ya da 2. dereceden polinomiyal denklem kullanılmaktadır. Yanıt doğrusal ise 1. dereceden değil ise 2. dereceden polinomiyal sistemler kullanılabilir. 2. dereceden polinomiyal model eşitliği Eşitlik 1 deki gibidir. $\beta 0, \beta \mathrm{i}, \beta \mathrm{ii}$ ve $\beta \mathrm{ij}$ sabit, doğrusal terimlerin, karesel terimlerin ve interaksiyon terimlerin regresyon katsayılarıdır, $\mathrm{Xi}$ ve $\mathrm{Xj}$ bağımsız değişkenlerin kodlarıdır.

$Y=\beta o \sum_{i=1}^{3} \beta i X i+\sum_{i=1}^{3} \beta i i X i i^{2}+\sum_{i=1}^{3} \sum_{j=1}^{3} \beta i j X i X j$

Bu denkleme göre 3 bağımsız değişken için modelin verdiği cevap için denklem ise aşağıda verildiği şekliyledir. Model uygunluğu testi ise (lack of fit) elde edilen verilerin regresyon modele uygunluğunun test edilmesi ile elde edilmektedir. Eşitlik 2'de Y bağımlı değişkenleri (ekstraksiyon verimi, toplam fenolik miktarı ve antioksidan aktivite ) $\beta_{0}$ sabit, $\beta_{1}, \beta_{2}$ ve $\beta_{3}$ lineer terimleri, $\beta_{4}, \beta_{5}$ ve $\beta_{6}$ kuadratik terimleri ve X1, X2 ve X3 bağımsız değişkenleri temsil etmektedir. Design-Expert 10 (Stat-Ease Inc., Minneapolis) programı elde edilen dataların regresyon ve grafiksel analizi için kullanılmıştır. Oleoresin ekstraksiyonu için denenen bağımsız değişkenlerin değerleri Tablo 1'de verilmiştir.

$Y=f(x)=\beta_{0}+\beta_{1} X_{1}+\beta_{2} X_{2}+\beta_{3} X_{3}+\beta_{4} X_{1}{ }^{2}+\beta_{5} X_{2}{ }^{2}+\beta_{6} X_{3}{ }^{2}+\beta_{7} X_{1} X_{2}+\beta_{8} X_{1} X_{3}+\beta_{9} X_{2} X_{3}$ 
European Journal of Science and Technology

Tablo1. Oleoresin ekstraksiyonunda beirlenen bağımsız değişsenler

\begin{tabular}{l|lll}
\hline \multirow{2}{*}{ Bağımsız Değişkenler } & RSM Seviyeleri & & \\
\cline { 2 - 4 } & $-\mathbf{1}$ & $\mathbf{0}$ & $\mathbf{1}$ \\
\hline Sıcaklık $\left({ }^{\circ} \mathbf{C}\right)$ & 30 & 40 & 50 \\
Süre (dk) & 10 & 20 & 30 \\
Örnek/çözücü oranı & $1 / 10$ & $1 / 30$ & $1 / 50$ \\
\hline
\end{tabular}

\section{Ekstraksiyon Verimi}

Ekstraksiyon işleminden sonra, ekstraktlar 5000 rpm'de 10 dakika santrifüjlenmiştir ardından filtre edilmiştir. Elde edilen oleoresinden rotary evaporatör kullanılarak çözgen tamamen uzaklaştırılmıştır. Oleoresinlerin ekstraksiyon verimi gravimetrik olarak hesaplanmıştır. Elde edilen ekstraktlar daha sonraki analizler için buzdolabı koşullarında saklanmıştır. Önerilen deney tasarımına göre elde edilen; $2 \mathrm{~g}$ toz zencefile ait oleoresinlerin $6 \mathrm{~mL}$ metanoldeki çözeltisi ile $2 \mathrm{~g}$ keten tohumuna ait oleoresinlerin $3 \mathrm{~mL}$ metanoldeki çözeltisi stok ekstraktlar olarak kullanılmıştır ve ilgili diğer analizlerin tamamı bu ekstraktlarda gerçekleştirilmiştir.

\section{Antiradikal Aktivitenin Belirlenmesi}

Antiradikal aktivite; DPPH (2,2-difenil-1-pikrilhidrazil) yöntemine göre belirlenmiştir. Yöntem radikalin karakteristik mor renginde meydana gelen renk değişikliğinin spektrofotometre ile ölçülmesi esasına dayanır. Antiradikal aktivite tayini Brand-Williams ve ark. (1995) tarafından önerilen yöntemde bazı değişiklikler uygulanarak yapılmıştır. Hazırlanan zencefil stok çözeltileri için, $10 \mu \mathrm{l}$

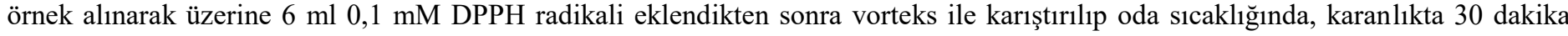
bekletilmiştir. Hazırlanan keten tohumu stok çözeltileri için, $100 \mu$ lalınarak üzerine $3 \mathrm{ml}$ 0,1 mM DPPH radikali eklendikten sonra vorteks ile karıştırılıp oda sıcaklığında, karanlıkta 30 dakika bekletilmiştir. Aynı işlem ekstre yerine çözücü içeren kör örnek için eş zamanlı olarak tekrarlanmıştır. Örneklerin absorbans değerleri $517 \mathrm{~nm}$ dalga boyunda spektrofotometre de (Agilent, Carry 60 UV-Vis, Amerika) okunmuş her bir örnek için ölçümler 4 kez tekrarlanarak gerçekleştirilmiştir. Ekstre çözeltilerinin serbest radikal temizleyici etkisi DPPH absorbsiyonunun \% inhibisyonu olarak belirtilmiştir. Bu değer aşağıdaki formüle göre hesaplanmıştır. Antiradikal Aktivite (\% İnhibisyon) = 100 x (1-Örnek Çözelti Absorbansi/Kör Çözelti Absorbansı)

\section{Toplam Fenolik Madde Miktarının Belirlenmesi}

Zencefil ve keten tohumu için toplam fenolik madde miktarı Singleton and Rossi (1965) tarafindan önerilen kolorimetrik bir yöntem olan Folin-Ciocalteu yöntemi üzerinde bazı modifikasyonlar yapılarak belirlenmiştir. Zencefil oleoresin örnekleri için, 2400 $\mu 1$ saf su, $30 \mu 1$ ekstrakt, 2 N $200 \mu 1$ Folin-Ciocalteu fenol ayıracı, $600 \mu 1 \% 20$ ' lik doymuş $\mathrm{Na}_{2} \mathrm{CO}_{3}$ çözeltisi ve $770 \mu 1$ saf su ilave edilip karıştırıldıktan sonra oda sıcaklığında, karanlık bir ortamda 120 dakika bekletilmiştir. Keten tohumu oleoresin örnekleri için de, $2400 \mu \mathrm{l}$ saf su, $50 \mu \mathrm{l}$ ekstrakt, $2 \mathrm{~N} 200 \mu \mathrm{l}$ Folin-Ciocalteu fenol ayıracı, $600 \mu 1 \% 20$ ' lik doymuş $\mathrm{Na}_{2} \mathrm{CO}_{3}$ çözeltisi ve $750 \mu 1$ saf su ilave edilip karıştırıldıktan sonra oda sıcaklığında, karanlık bir ortamda 120 dakika bekletilmiştir. Süre sonunda örneklerin absorbansı $765 \mathrm{~nm}$ dalga boyunda spektrofotometrede (Agilent, Carry 60 UV-Vis, Amerika) ölçülmüştür. Sonuçlar gallik asit eşdeğeri (GAE) olarak hesaplanmıştır.

\section{Araştırma Sonuçları ve Tartışma}

Yüksek oranda fenolik ve antioksidan aktivite içeren zencefil ve keten tohumu oleoresinlerin ekstraksiyonunda proses faktörlerinin (sıcaklık, süre ve çözücü oranı) oleoresinlerdeki toplam fenolik madde, antioksidan aktivite ve ekstraksiyon verimine etkisi yanıt yüzey metodolojisi ile Box- Benkhen tasarımı ile incelenmiş̧ir. İncelenen koşullar ve elde edilen veriler Design Expert yazılımı tarafindan analiz edilerek önerilen uygun fonksiyonlar belirlenmiştir. Bu belirleme yapılırken "Lack of fit" testleri yapılmış, her bir fonksiyon için standart sapma, $R^{2}$ (R-squared), düzeltilmiş $R^{2}$ ve öngörülen $R^{2}$ değerleri göz önünde bulundurulmuştur. $B u$ değerler karşılaştırılarak en uygun fonksiyon yazılım tarafindan belirlenmiştir.

\subsection{Ekstraksiyon Verimi}

Uygulanan ekstraksiyon sıcaklığı, ekstraksiyon süresi ve çözücü oranında yanıt yüzey yöntemi ile yapılan deneme desenine göre elde edilen cevap (oleoresinlerin ekstraksiyon verimi) üzerine etkisini ortaya koyan polinomiyal modele ait eşitlik, ANOVA tablosu ve yanıt yüzey grafikleri tablo ve şekillerde verilmektedir.

Zencefil ve keten tohumu için ayrı ayrı uygulanan Box- Benkhen tasarımında, doğrusal, kübik, kuadratik ve iki faktörlü etkileşim modelleri incelenmiş̧ir. İnceleme neticesinde ekstraksiyon koşullarında her iki örnekte de elde edilen verileri en iyi açıklayan modelin kuadratik model olduğu belirlenmiştir. Bu modele ait varyans analiz sonuçları Tablo 2 ve Tablo 3 'te gösterilmiştir. Buna göre modele ait $p$-değerinin 0.05 'den küçük olması ve uyum eksikliğinin önemsiz çıkması kuadratik modelin deneysel verilerle tatmin edici düzeyde uyumlu olduğunu göstermektedir. 
Avrupa Bilim ve Teknoloji Dergisi

\section{Zencefil}

Tablo 2. Zencefil oleoresinlerinin ekstraksiyon verimine ait ANOVA Çizelgesi

\begin{tabular}{|c|c|c|c|c|c|}
\hline $\begin{array}{l}\text { Kaynak } \\
\text { Source } \\
\end{array}$ & $\begin{array}{l}\text { Kareler toplamı } \\
\text { Sum of squares }\end{array}$ & $\begin{array}{l}\text { Serbestlik Derecesi } \\
\text { Degree of freedom }\end{array}$ & $\begin{array}{l}\text { Karelerin ortalaması } \\
\text { Average of squares }\end{array}$ & $\begin{array}{l}\text { F-değeri } \\
\text { F-value }\end{array}$ & $\begin{array}{l}\text { p-değeri } \\
\text { p-Value } \\
\end{array}$ \\
\hline $\begin{array}{l}\text { Model } \\
\text { Model }\end{array}$ & 228,95 & 0 & 25,44 & 106,90 & $\begin{array}{l}<\quad 0.0001 \\
\text { Önemli }\end{array}$ \\
\hline $\begin{array}{l}\text { Residual } \\
\text { Residual }\end{array}$ & 1,72 & 5 & 0,3438 & & \\
\hline $\begin{array}{l}\text { Uyum Eksikliği } \\
\text { Lack of fit }\end{array}$ & 1,15 & 3 & 0,3825 & 18,06 & $\begin{array}{l}\text { 0,0529 } \\
\text { Önemsiz }\end{array}$ \\
\hline $\begin{array}{l}\text { Hata } \\
\text { Pure error }\end{array}$ & 0,0424 & 2 & 0,0212 & & \\
\hline $\begin{array}{l}\text { Genel } \\
\text { Total }\end{array}$ & 230,13 & 14 & & & \\
\hline
\end{tabular}

Zencefilden oleoresinlerin ekstraksiyonunda model çıktısı ANOVA tablosu (Tablo 2) ve ekstraksiyon verimi üzerine sıcaklık, süre ve çözücü miktarının etkisini gösteren cevap yüzey grafikleri (Şekil 1) incelendiğinde toplam ekstraksiyon verimi üzerine, örnek çözücü oranı en etkili $(p<0.0001)$ parametre olmuştur ve sıcaklık da yine istatistiksel olarak önemli $(p<0.05)$ bir parametre olarak bulunmuştur. Ekstraksiyon süresi ise istatistiksel olarak önemsiz bulunmuştur $(p>0.05)$. Regresyon analizi sonucunda ekstraksiyon veriminin $(Y)$ hesaplanması için oluşturulan kuadratik polinomiyal denklem ise aşağıda gösterilmiştir.
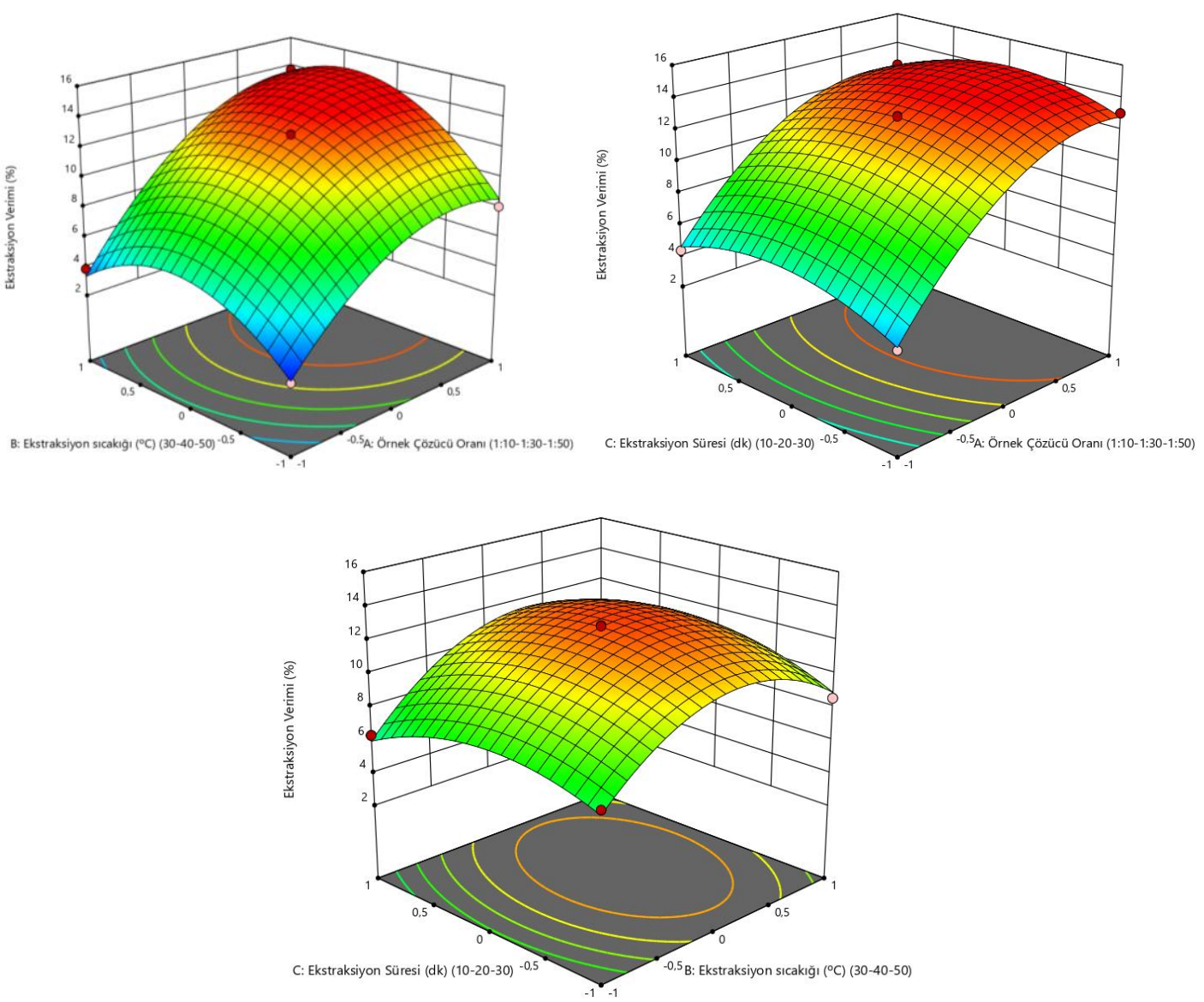

Şekil 1. Zencefil oleoresinlerinin ekstraksiyon verimine ait cevap yüzey grafikleri 
European Journal of Science and Technology

\section{Keten Tohumu}

Tablo 3. Keten tohumu oleoresinlerinin ekstraksiyon verimine ait ANOVA Çizelgesi

\begin{tabular}{|c|c|c|c|c|c|}
\hline $\begin{array}{l}\text { Kaynak } \\
\text { Source } \\
\end{array}$ & $\begin{array}{l}\text { Kareler toplamı } \\
\text { Sum of squares }\end{array}$ & $\begin{array}{l}\text { Serbestlik Derecesi } \\
\text { Degree of freedom }\end{array}$ & $\begin{array}{l}\text { Karelerin ortalaması } \\
\text { Average of squares }\end{array}$ & $\begin{array}{l}\text { F-değeri } \\
\text { F-value }\end{array}$ & $\begin{array}{l}\text { p-değeri } \\
\text { p-Value }\end{array}$ \\
\hline $\begin{array}{l}\text { Model } \\
\text { Model }\end{array}$ & 1511,62 & 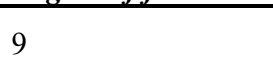 & 167,96 & 488,48 & $\begin{array}{l}<\quad 0.0001 \\
\text { Önemli }\end{array}$ \\
\hline $\begin{array}{l}\text { Residual } \\
\text { Residual }\end{array}$ & 1,72 & 5 & 0,3438 & & \\
\hline $\begin{array}{l}\text { Uyum Eksikliği } \\
\text { Lack of fit }\end{array}$ & 1,65 & 3 & 0,5505 & 16,27 & $\begin{array}{l}0,0529 \\
\text { Önemsiz }\end{array}$ \\
\hline $\begin{array}{l}\text { Hata } \\
\text { Pure error }\end{array}$ & 0,0677 & 2 & 0,0338 & & \\
\hline $\begin{array}{l}\text { Genel } \\
\text { Total }\end{array}$ & 1513,34 & 14 & & & \\
\hline
\end{tabular}

Keten tohumundan oleoresinlerin ekstraksiyonunda model çıktısı ANOVA tablosu (Tablo 3) ve ekstraksiyon verimi üzerine sıcaklık, süre ve çözücü miktarının etkisini gösteren cevap yüzey grafikleri (Şekil 2) incelendiğinde, örnek çözücü oranı, sıcaklık ve ekstraksiyon süresinin toplam ekstraksiyon verimi üzerine etkisi $(p<0.0001)$ istatistiksel olarak önemli bulunmuştur. Regresyon analizi sonucunda ekstraksiyon veriminin $(Y)$ hesaplanması için oluşturulan kuadratik polinomiyal denklem ise aşağıda gösterilmiştir.
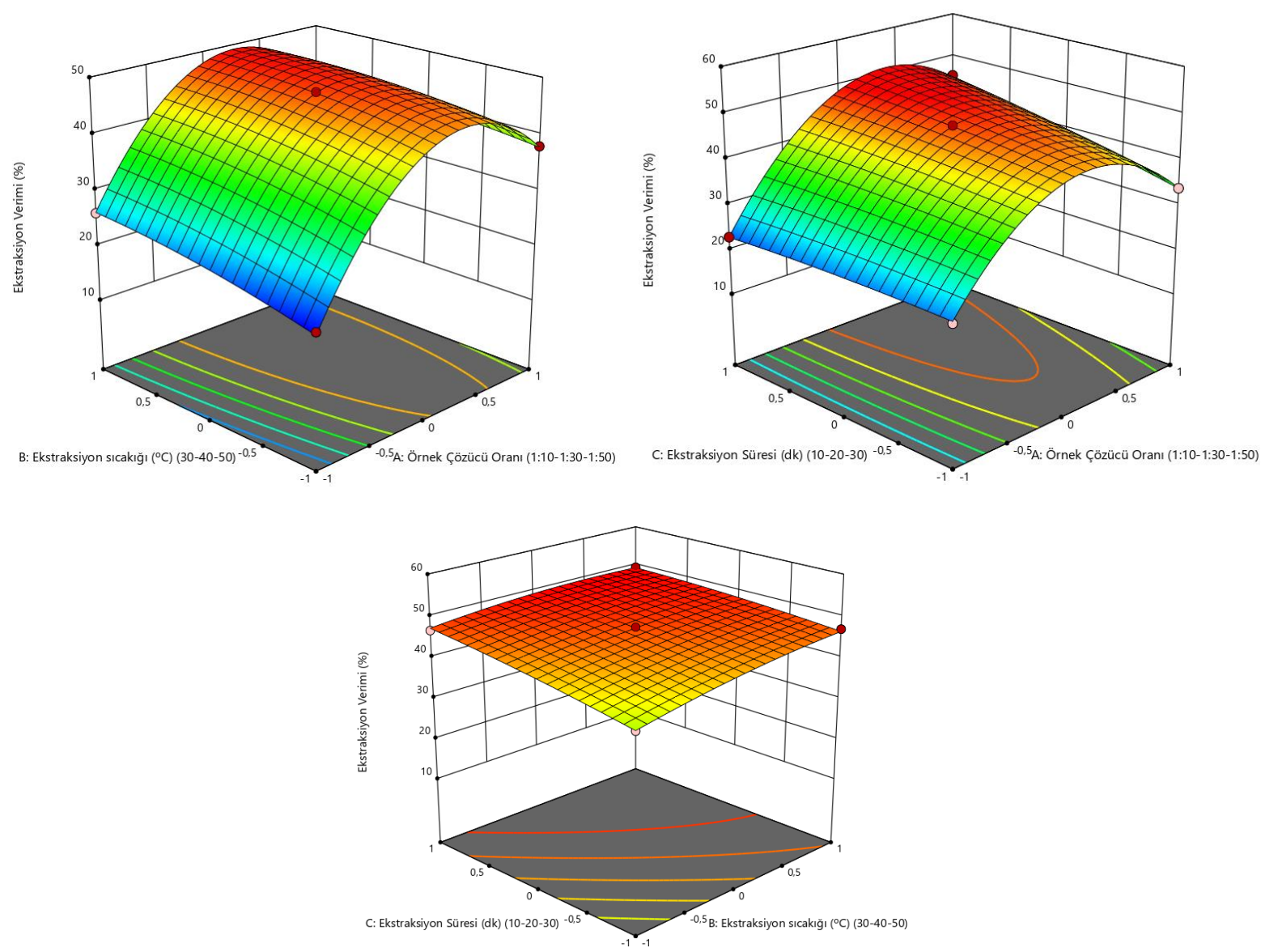

Şekil 2. Keten tohumu oleoresinlerinin ekstraksiyon verimine ait cevap yüzey grafikleri

\subsection{Antiradikal Aktivite}

Keten tohumu ve zencefil için ayrı ayrı uygulanan Box- Benkhen tasarımında, doğrusal, kübik, kuadratik ve iki faktörlü etkileşim modelleri incelenmiştir. Ekstraksiyon koşullarında her iki örnekte de elde edilen verileri en iyi açıklayan modelin kuadratik model olduğu sonucuna varılmıştır. Bu modele ait varyans analiz sonuçları Tablo 4 ve Tablo 5 'te gösterilmiştir. Buna göre antiradikal aktivitenin belirlenmesinde modellere ait $p$-değerinin 0.05 'den küçük olması ve uyum eksikliğinin önemsiz çıkması kuadratik modelin deneysel verilerle tatmin edici düzeyde uyumlu olduğunu göstermektedir. 
Avrupa Bilim ve Teknoloji Dergisi

\section{Zencefil}

Tablo 4. Zencefil oleoresinlerinin antiradikal aktivite değerlerine ait ANOVA Çizelgesi

\begin{tabular}{|c|c|c|c|c|c|}
\hline $\begin{array}{l}\text { Kaynak } \\
\text { Source } \\
\end{array}$ & $\begin{array}{l}\text { Kareler toplamı } \\
\text { Sum of squares }\end{array}$ & $\begin{array}{l}\text { Serbestlik Derecesi } \\
\text { Degree of freedom }\end{array}$ & $\begin{array}{l}\text { Karelerin ortalaması } \\
\text { Average of squares }\end{array}$ & $\begin{array}{l}\text { F-değeri } \\
\text { F-value }\end{array}$ & $\begin{array}{l}\text { p-değeri } \\
\text { p-Value } \\
\end{array}$ \\
\hline $\begin{array}{l}\text { Model } \\
\text { Model }\end{array}$ & 1369.98 & 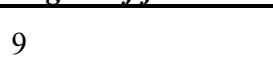 & 152.22 & 845.93 & $\begin{array}{l}<\quad 0.0001 \\
\text { Önemli }\end{array}$ \\
\hline $\begin{array}{l}\text { Residual } \\
\text { Residual }\end{array}$ & 0.8997 & 5 & 0.1799 & & \\
\hline $\begin{array}{l}\text { Uyum Eksikliği } \\
\text { Lack of fit }\end{array}$ & 0.6499 & 3 & 0.2166 & 1.73 & $\begin{array}{l}0.3860 \\
\text { Önemsiz }\end{array}$ \\
\hline $\begin{array}{l}\text { Hata } \\
\text { Pure error }\end{array}$ & 0.2498 & 2 & 0.1249 & & \\
\hline $\begin{array}{l}\text { Genel } \\
\text { Total }\end{array}$ & 1370.88 & 14 & & & \\
\hline
\end{tabular}

Değerlendirme parametreleri antiradikal aktivite tahmininde model performansının yüksek olduğunu göstermektedir ( $\mathrm{R}^{2}$ : 0.9993). Şekil 3'de zencefilden elde edilen oleoresinlerin antiradikal aktivite üzerine sıcaklık, süre ve çözücü miktarının etkisini gösteren cevap yüzey grafikleri gösterilmiştir. Zencefilden oleoresinlerin ekstraksiyonunda model çıktısı ANOVA tablosu (Tablo 4) ve Şekil 3 incelendiğinde antiradikal aktivite üzerine, örnek çözücü oranı ve ekstraksiyon sıcaklığ en etkili $(p<0.0001)$ parametreler olmuşken; ekstraksiyon süresi ise istatistiksel olarak önemsiz bulunmuştur $(p>0.05)$. Regresyon analizinden elde edilen, antiradikal aktivitenin $(Y)$ hesaplanması için oluşturulan kuadratik polinomiyal denklem ise aşağıda gösterilmiştir.
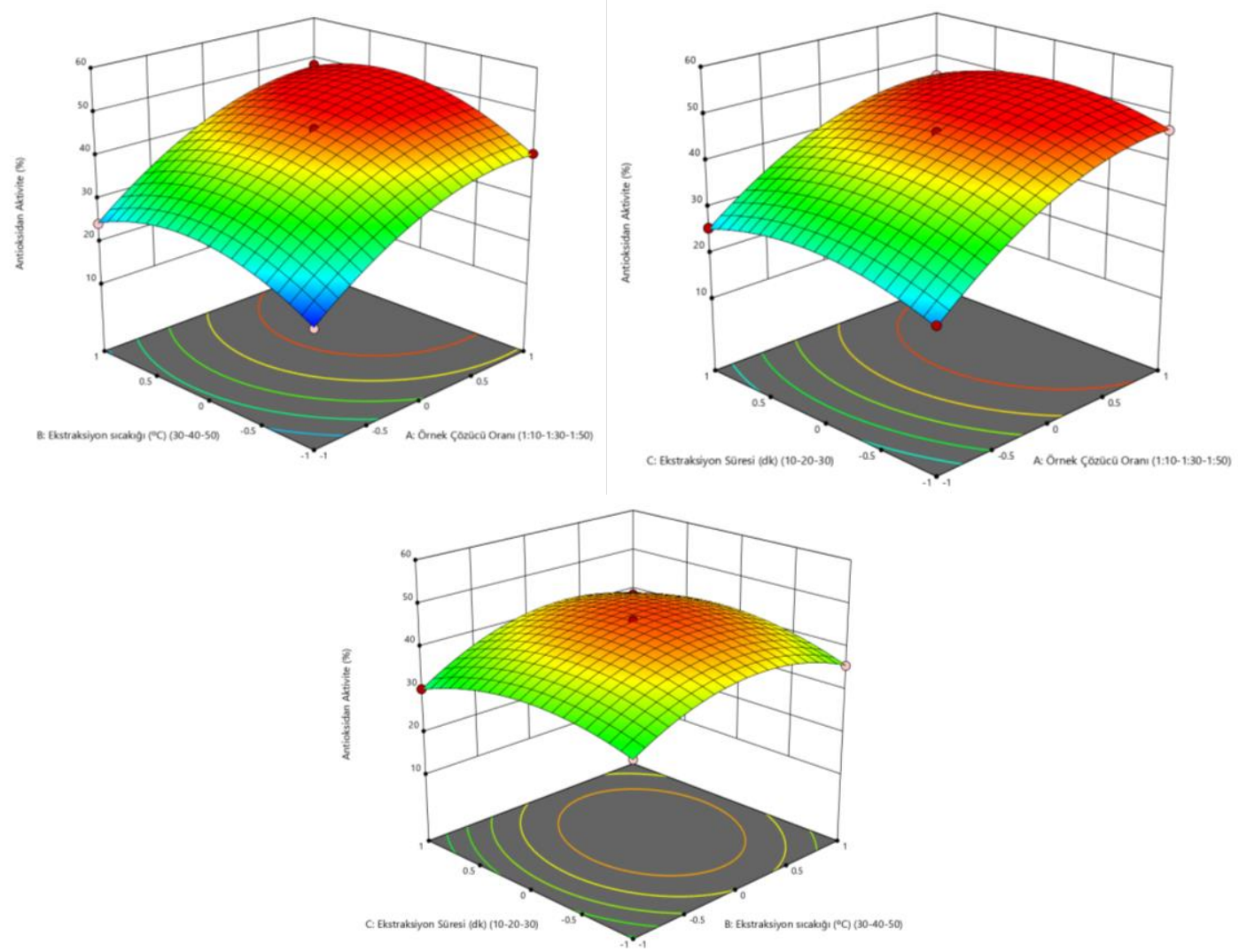

Şekil 3. Zencefil oleoresinlerinin antiradikal aktivite değerlerine ait cevap yüzey grafikleri 
European Journal of Science and Technology

Keten Tohumu

Tablo 5. Keten tohumu oleoresinlerinin antiradikal aktivite değerlerine ait ANOVA Çizelgesi

\begin{tabular}{|c|c|c|c|c|c|}
\hline $\begin{array}{l}\text { Kaynak } \\
\text { Source } \\
\end{array}$ & $\begin{array}{l}\text { Kareler toplamı } \\
\text { Sum of squares }\end{array}$ & $\begin{array}{l}\text { Serbestlik Derecesi } \\
\text { Degree of freedom }\end{array}$ & $\begin{array}{l}\text { Karelerin ortalamasi } \\
\text { Average of squares }\end{array}$ & $\begin{array}{l}\text { F-değeri } \\
\text { F-value }\end{array}$ & $\begin{array}{l}\text { p-değeri } \\
\text { p-Value }\end{array}$ \\
\hline $\begin{array}{l}\text { Model } \\
\text { Model }\end{array}$ & 489,46 & 9 & 54,38 & 122,47 & $\begin{array}{l}<\quad 0.0001 \\
\text { Önemli }\end{array}$ \\
\hline $\begin{array}{l}\text { Residual } \\
\text { Residual }\end{array}$ & 2,22 & 5 & 0,4441 & & \\
\hline $\begin{array}{l}\text { Uyum Eksikliği } \\
\text { Lack of fit }\end{array}$ & 2,13 & 3 & 0,7100 & 15,73 & $\begin{array}{l}0,0604 \\
\text { Onnemli }\end{array}$ \\
\hline $\begin{array}{l}\text { Hata } \\
\text { Pure error }\end{array}$ & 0,0903 & 2 & 0,0451 & & \\
\hline $\begin{array}{l}\text { Genel } \\
\text { Total }\end{array}$ & 491,68 & 14 & & & \\
\hline
\end{tabular}

Değerlendirme parametreleri antiradikal aktivite tahmininde model performansının yüksek olduğunu göstermektedir (R2: 0.9955). Şekil 4'de keten tohumundan elde edilen oleoresinlerin antiradikal aktivite üzerine sıcaklık, süre ve çözücü miktarının etkisini gösteren cevap yüzey grafikleri gösterilmiştir. Keten tohumundan oleoresinlerin ekstraksiyonunda model çıtısı ANOVA tablosu (Tablo 5) ve Şekil 4 incelendiğinde toplam ekstraksiyon verimi üzerine, örnek çözücü oranı en etkili $(p<0.0001)$ parametre olmuştur ve süre de yine istatistiksel olarak önemli $(p<0.05)$ bir parametre olarak bulunmuştur. Ekstraksiyon sıcaklığı ise antiradikal aktivite üzerine istatistiksel olarak önemsiz bulunmuştur $(p>0.05)$. Regresyon analizi sonucunda antiradikal aktivitenin $(Y)$ hesaplanması için oluşturulan kuadratik polinomiyal denklem ise aşağıda gösterilmiştir.
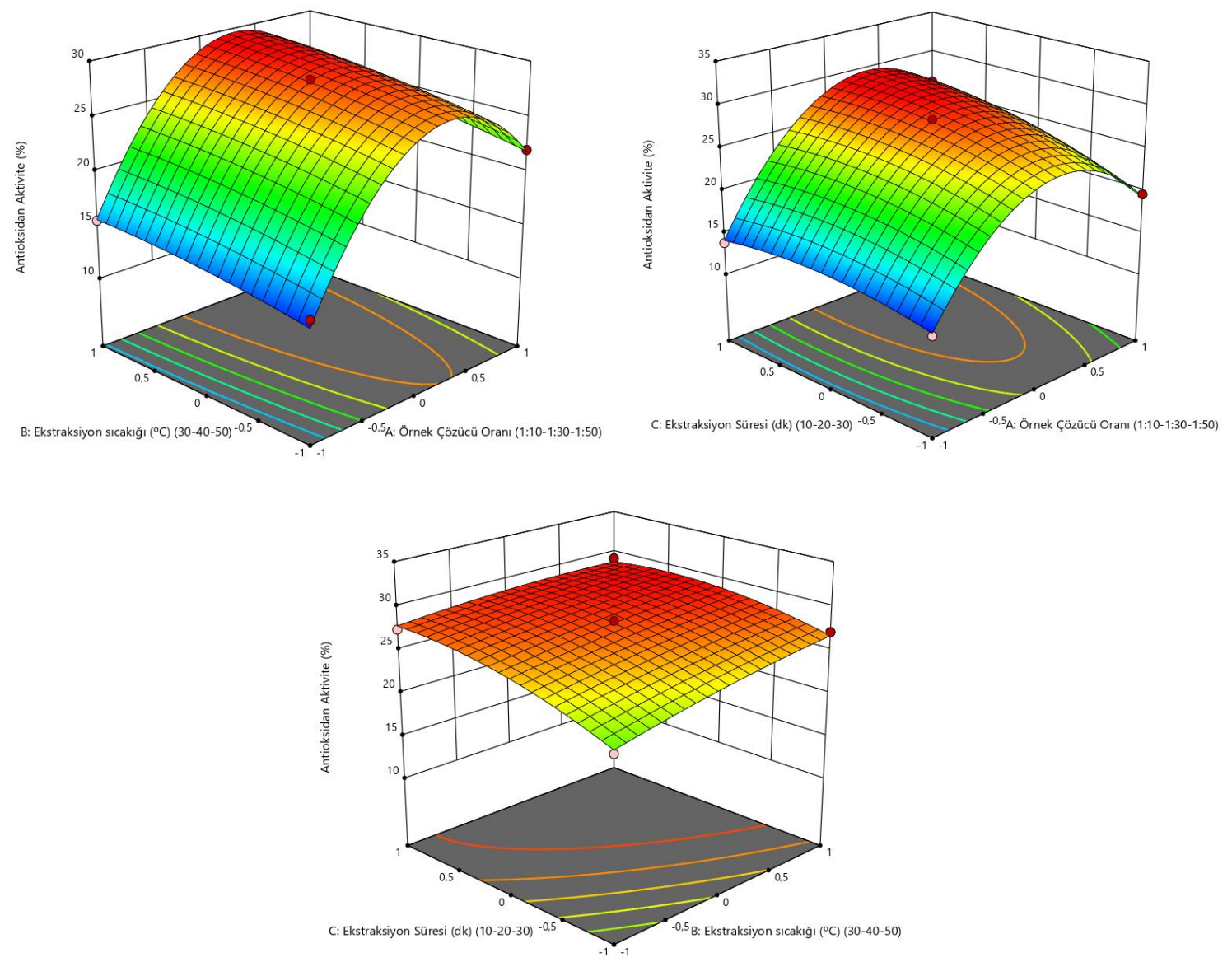

Şekil 4. Keten tohumu oleoresinlerinin antiradikal aktivite değerlerine ait cevap yüzey grafikleri 


\subsection{Toplam Fenolik Miktarı}

Zencefil ve keten tohumu için ayrı ayrı uygulanan Box- Benkhen tasarımında, doğrusal, kübik, kuadratik ve iki faktörlü etkileşim modelleri incelenmiştir. İnceleme neticesinde ekstraksiyon koşullarında her iki örnekte de elde edilen verilerin deneme desenine göre elde edilen cevap (toplam fenolik miktarı) üzerine etkisini en iyi açıklayan modelin kuadratik model olduğu belirlenmiştir. Bu modele ait varyans analiz sonuçları Tablo 6 ve Tablo 7'de gösterilmiştir. Buna göre modele ait $p$-değerinin 0.05 'den küçük olması ve uyum eksikliğinin önemsiz çıkması kuadratik modelin deneysel verilerle oldukça uyumlu olduğunu göstermektedir.

\section{Zencefil}

Zencefil oleoresinlerin ekstraksiyonunda model çıktısı ANOVA tablosu (Tablo 6) ve toplam fenolik madde miktarı üzerine sıcaklık, süre ve çözücü miktarının etkisini gösteren cevap yüzey grafikleri (Şekil 5) incelendiğinde toplam fenolik madde miktarı üzerine, örnek çözücü oranı ve ekstraksiyon sıcaklığı en etkili $(p<0.0001)$ parametre olurken; süre ise toplam fenolik madde miktarı üzerine istatistiksel olarak önemsiz bulunmuştur $(p>0.05)$. Toplam fenolik miktarının $(Y)$ hesaplanması için oluşturulan kuadratik polinomiyal denklem ise aşağıda gösterilmiştir.

$\mathrm{Y}=392.57+92.63 \mathrm{~A}+34.26 \mathrm{~B}+0.7966 \mathrm{C}+23.83 \mathrm{AB}-3.18 \mathrm{AC}+11.80 \mathrm{BC}-59.63 \mathrm{~A}^{2}-72.33 \mathrm{~B}^{2}-38.04 \mathrm{C}^{2}$

Tablo 6. Zencefil oleoresinlerinin toplam fenolik değerlerine ait ANOVA Çizelgesi

\begin{tabular}{|c|c|c|c|c|c|}
\hline $\begin{array}{l}\text { Kaynak } \\
\text { Source }\end{array}$ & $\begin{array}{l}\text { Kareler toplamı } \\
\text { Sum of squares }\end{array}$ & $\begin{array}{l}\text { Serbestlik Derecesi } \\
\text { Degree of freedom }\end{array}$ & $\begin{array}{l}\text { Karelerin ortalaması } \\
\text { Average of squares }\end{array}$ & $\begin{array}{l}\text { F-değeri } \\
\text { F-value }\end{array}$ & $\begin{array}{l}\text { p-değeri } \\
\text { p-Value }\end{array}$ \\
\hline $\begin{array}{l}\text { Model } \\
\text { Model }\end{array}$ & $1.141 \mathrm{E}+05$ & 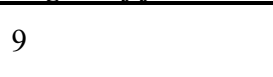 & 12681.24 & 132.83 & $\begin{array}{l}<\quad 0.0001 \\
\text { Önemli }\end{array}$ \\
\hline $\begin{array}{l}\text { Residual } \\
\text { Residual }\end{array}$ & 477.34 & 5 & 95.47 & & \\
\hline $\begin{array}{l}\text { Uyum Eksikliği } \\
\text { Lack of fit }\end{array}$ & 455.21 & 3 & 151.74 & 13.72 & $\begin{array}{l}0.0687 \\
\text { Önemsiz }\end{array}$ \\
\hline $\begin{array}{l}\text { Hata } \\
\text { Pure error }\end{array}$ & 22.13 & 2 & 11.06 & & \\
\hline $\begin{array}{l}\text { Genel } \\
\text { Total }\end{array}$ & $1.146 \mathrm{E}+05$ & 14 & & & \\
\hline
\end{tabular}

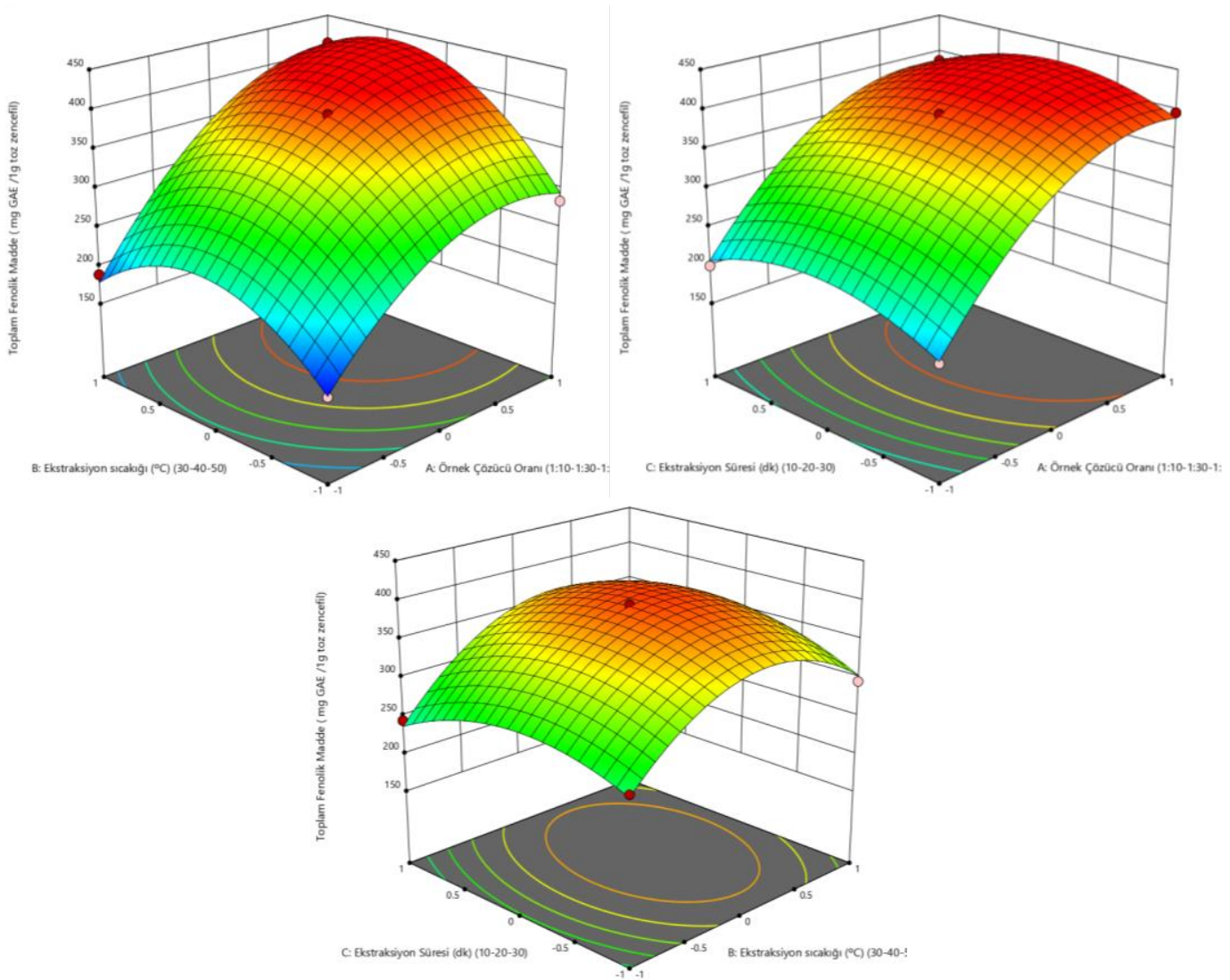

Şekil 5. Zencefil oleoresinlerinin toplam fenolik değerlerine ait cevap yüzey grafikleri 


\section{Keten tohumu}

Keten tohumu oleoresinlerin ekstraksiyonunda model çıktısı ANOVA tablosu (Tablo 7) ve toplam fenolik madde miktarı üzerine sıcaklık, süre ve çözücü miktarının etkisini gösteren cevap yüzey grafikleri (Şekil 6) incelendiğinde, belirlenen tüm bağımsız değişkenlerin; örnek çözücü oranı, ekstraksiyon sıcaklığı ve ekstraksiyon süresinin $(p<0.0001)$ toplam fenolik madde miktarı üzerine önemli derecede etkili olduğu bulunmuştur. Toplam fenolik miktarının (Y) hesaplanması için oluşturulan kuadratik polinomiyal denklem ise aşağıda gösterilmiştir.

Tablo 7. Keten tohumu oleoresinlerinin toplam fenolik değerlerine ait ANOVA Çizelgesi

\begin{tabular}{|c|c|c|c|c|c|}
\hline $\begin{array}{l}\text { Kaynak } \\
\text { Source } \\
\end{array}$ & $\begin{array}{l}\text { Kareler toplamı } \\
\text { Sum of squares }\end{array}$ & $\begin{array}{l}\text { Serbestlik Derecesi } \\
\text { Degree of freedom }\end{array}$ & $\begin{array}{l}\text { Karelerin ortalaması } \\
\text { Average of squares }\end{array}$ & $\begin{array}{l}\text { F-değeri } \\
\text { F-value }\end{array}$ & $\begin{array}{l}\text { p-değeri } \\
\text { p-Value }\end{array}$ \\
\hline $\begin{array}{l}\text { Model } \\
\text { Model }\end{array}$ & 10821,13 & 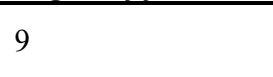 & 1202,35 & 1406,05 & $\begin{array}{l}<\quad 0.0001 \\
\text { Önemli }\end{array}$ \\
\hline $\begin{array}{l}\text { Residual } \\
\text { Residual }\end{array}$ & 4,28 & 5 & 0,8551 & & \\
\hline $\begin{array}{l}\text { Uyum Eksikliği } \\
\text { Lack of fit }\end{array}$ & 2,63 & 3 & 0,8774 & 1,07 & $\begin{array}{l}0,5169 \\
\text { Önemsiz }\end{array}$ \\
\hline $\begin{array}{l}\text { Hata } \\
\text { Pure error }\end{array}$ & 1,64 & 2 & 0,8216 & & \\
\hline $\begin{array}{l}\text { Genel } \\
\text { Total }\end{array}$ & 10825,40 & 14 & & & \\
\hline $\mathrm{R}^{2}: 0.9996 \mathrm{Ac}$ & $2: 0.9989 \quad$ C.V. $\%$ & .5958 & & & \\
\hline
\end{tabular}
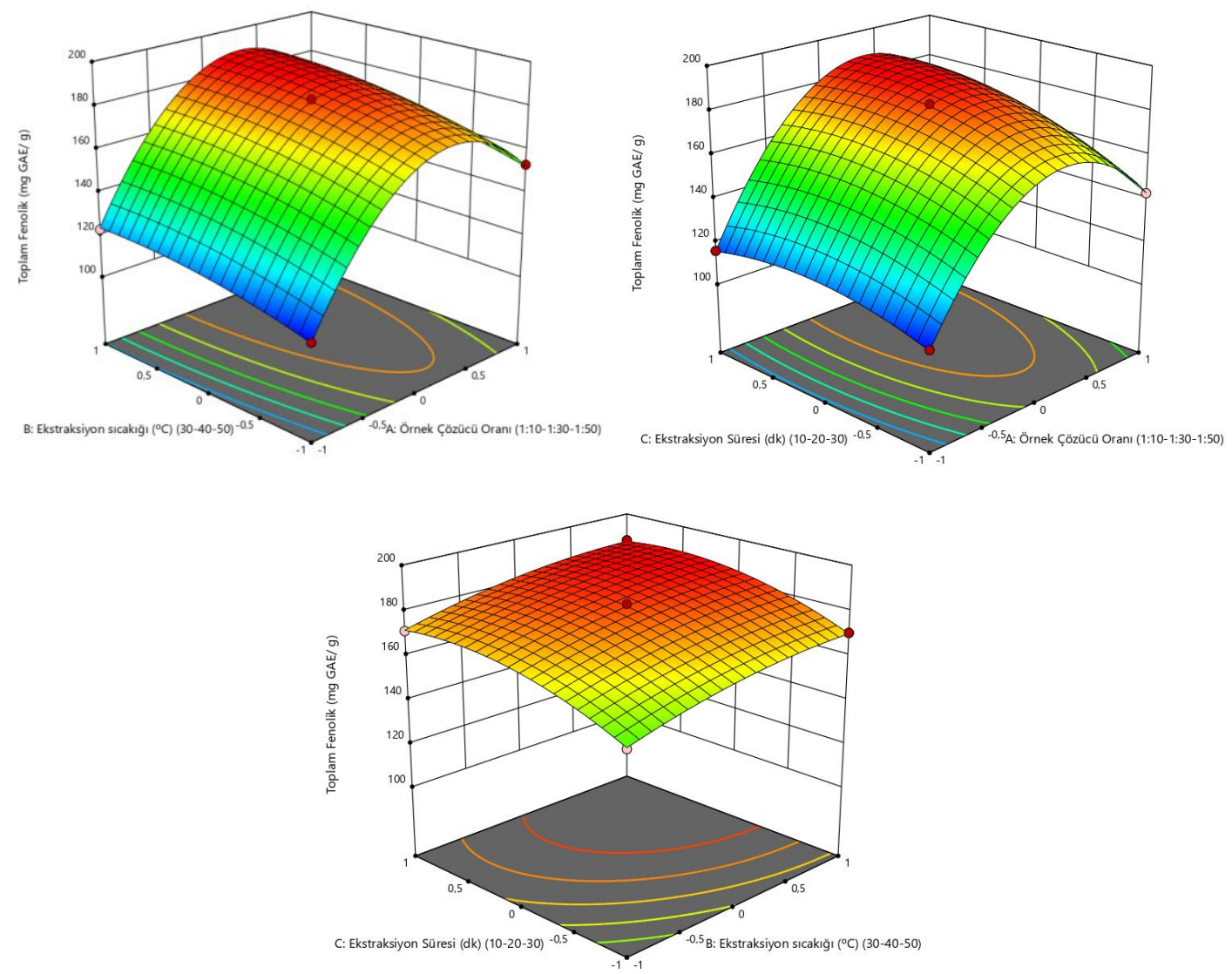

Şekil 6. Keten tohumu oleoresinlerinin toplam fenolik değerlerine ait cevap yüzey grafikleri 
Yapılan çalışmada gerçekleştirilen ekstraksiyon koşullarında zencefil için maksimum toplam fenolik miktarı 412,37 mg GAE/100g, keten tohumu için ise maksimum toplam fenolik miktarı 187,2 mg GAE/100g olarak bulunmuştur. Yeh ve arkadaşları (2014) Tayland da bulunan iki çeşit zencefil kökünün sulu ve etanolik ekstraktlarını kullanarak antioksidan özelliklerini ve biyoaktif bileşenlerini karşılaştırmışlardır. Her iki çözücüde de birtakım farklı sonuçlara ulaşmışlardır. Zencefilin etanolik ekstraktların antioksidan etkisi trolox eşdeğeri antioksidan kapasitede ve demir indirgeyici plazma kapasitesinde sulu özütlerden daha etkili bulunurken; aksine, zencefilin sulu ekstraktları serbest radikal süpürmede daha etkili olmuştur. Zancan ve arkadaşları (2002) zencefil oleoresinlerini süperkritik akışkan ekstraksiyonu ile ekstrakte etmişler ve ekstraksiyon koşullarının oleoresinin karakteristiği üzerine etkisini araştırmışlardır. Süperkritik akışkan ekstraksiyonunda işletme değişkenlerinin etkilerini (basınç, sıcaklık, çözücü tipi), zencefil oleoresinin kimyasal bileşimi üzerinde istatistiksel olarak anlamlı bulmuşlardır. Elde ettikleri sonuçlara göre oleoresinin antioksidan aktivitesinin artırılması için etanol ya da izopropil alkol gibi bir çözücü desteğine ihtiyaç bulunmaktadır. Nile ve Park 2015, zencefil köklerinden seçici ekstraksiyon prosedürü ile farklı polarite çözücüler kullanarak çalışılan parametrelere karşı biyoaktivite farkını ortaya koymuşlardır. Etil asetat özü DPPH, FRAP ve $\mathrm{H}_{2} \mathrm{O}_{2}$ testi ile incelenen parametrelerde önemli antioksidan aktivite göstermiştir. Etanol ile yakın sonuçlar elde edilmiştir. Daha sonraki sırada ise; dietileter ve n- bütanol ekstraktları gelmiştir. Kırmızı ve beyaz zencefilin antioksidan özelliklerinin incelendiği bir çalışmada askorbik asit içeriğinin sırasıyla 1,83 ve 0,91 mmol/ $100 \mathrm{~g}$ taze meyve, toplam fenolik madde miktarı sırasıyla 95,34 ve 61,89 mmol GAE/ $100 \mathrm{~g}$ taze meyve olarak bildirilmiştir (Oboh ve ark., 2012). Zencefilin yaprak, gövde ve kök kısımlarının antioksidan özelliklerinin araştırıldığı bir çalışmada, Halia Bentong türü için fenolik madde içerikleri üç kısım için sırasıyla 33,0, 7,8 ve 10,22 mg GAE/ g km olarak bulunmuştur. $42.3 \mu \mathrm{g} / \mathrm{mL}$ metanol ekstraktı ile DPPH radikali giderme aktivitesi üzerinden hesaplanan antioksidan aktivite ise yaprak, gövde ve kök kısımları için sırasıyla \%51.12, \% 32.85 ve \%51.41 olarak saptanmıştır (Ghasemzadeh ve ark., 2010). Bir çalışmada farklı çözücüler kullanan keten tohumundan ekstrakte edilen toplam flavonoid (TF) miktarları 190-480 mg CE / $100 \mathrm{~g}$ öz şeklinde değişmektedir. Saf metanol kullanarak en yüksek miktarda TF'yi (480 mg CE / $100 \mathrm{~g}$ ) ekstrakte edilmiş daha düşük miktarlar saf etanol (190 mg CE / $100 \mathrm{~g})$ ile elde edilmiştir (Anwar ve Przybylski, 2012).

\section{Sonuç}

Sonuç olarak deneysel veriler ve tahmin edilen veriler arasındaki uyumu gösteren ilişki katsayısı $\left(\mathrm{R}^{2}\right)$ değeri tüm analizlerde $>0.99$ olarak elde edilmiştir. Bu değer; uygulanan model ile deneysel verilerin \% 99 doğrulukta açıklanabileceğini ifade etmektedir. Bu sonuç 20 deneysel nokta kullanılarak elde edilen model denklemin oleoresin elde edilmesi için incelenen bağımsız değişken aralığında yüksek doğrulukta kullanılabilirliğini göstermektedir.

Zencefilden toplam fenolik miktarı, antiradikal aktivitesi ve ekstraksiyon verimi yüksek olan oleoresin elde edilmesinde; örnek çözücü oranı $1 / 40$, sicaklık $42,5^{\circ} \mathrm{C}$ ve ekstraksiyon süresi 22 dakika olarak optimize edilmiştir. Keten tohumundan elde edilen oleoresin için program cevaplarının maksimum değerde olduğu koşullar; örnek çözücü oranı $1 / 35$, sıcaklık $41,3^{\circ} \mathrm{C}$ ve ekstraksiyon süresi 27 dakika olarak optimize edilmiştir. Literatürdeki benzer çalışmalar incelendiğinde oleoresinlerin elde edilmesinde ve aktivitelerinin belirlenmesinde elde edilen bulgular birbirinden farklılık göstermektedir. Bu da hammadde, çözücü ve kullanılan yöntemlerin farklılığından kaynaklanmaktadır. Çalışmamızda elde edilen sonuçlar diğer çalışmalarla karşılaştırılabilir niteliktedir.

\section{Teşekkür}

Bu çalışmanın gerçekleştirilmesine MF061218L02 proje numarası ile finansal destek sağlayan Çankırı Karatekin Üniversitesi Bilimsel Araştırma Projeleri Birimi’ne teşekkür ederiz.

\section{Kaynakça}

Anwar, F., \& Przybylski, R. (2012). Effect of solvents extraction on total phenolics and antioxidant activity of extracts from flaxseed (Linum usitatissimum L.). ACTA Scientiarum Polonorum Technologia Alimentaria, 11(3), 293-302.

Beejmohun, V., Fliniaux, O., Grand, É., Lamblin, F., Bensaddek, L., Christen, P., ... \& Mesnard, F. (2007). Microwave-assisted extraction of the main phenolic compounds in flaxseed. Phytochemical Analysis: An International Journal of Plant Chemical and Biochemical Techniques, 18(4), 275-282.

Bekdeşer, B. Yanıt Yüzey Metodolojisi Kullanılarak Dulavratotu (Arctium Lappa)'dan Antioksidanların Mikrodalga Destekli Ekstraksiyonunun Modellenmesi ve Optimizasyonu. Avrupa Bilim ve Teknoloji Dergisi, (17), 655-662.

Brand-Williams, W., Cuvelier, M. E. and Berset, C., (1994). Use of free radical method to evaluate antioxidant activity. LebensmittelWissenschaft \& Technologie, 28, 25-30.

Chan, E. W. C., Lim, Y. Y., \& Omar, M. (2007). Antioxidant and antibacterial activity of leaves of Etlingera species (Zingiberaceae) in Peninsular Malaysia. Food chemistry, 104(4), 1586-1593.

Ding, S. H., An, K. J., Zhao, C. P., Li, Y., Guo, Y. H., \& Wang, Z. F. (2012). Effect of drying methods on volatiles of Chine se ginger (Zingiber officinale Roscoe). Food and bioproducts processing, 90(3), 515-524.

Eliasson, C., Kamal-Eldin, A., Andersson, R., \& Åman, P. (2003). High-performance liquid chromatographic analysis of secoisolariciresinol diglucoside and hydroxycinnamic acid glucosides in flaxseed by alkaline extraction. Journal of chromatography A, 1012(2), 151-159.

Fliniaux, O., Corbin, C., Ramsay, A., Renouard, S., Beejmohun, V., Doussot, J., ... \& Roscher, A. (2014). Microwave-assisted extraction of herbacetin diglucoside from flax (Linum usitatissimum L.) seed cakes and its quantification using an RP-HPLC-UV system. Molecules, 19(3), 3025-3037. 
Ghasemzadeh, A., Jaafar, H. Z., \& Rahmat, A. (2010). Antioxidant activities, total phenolics and flavonoids content in two varieties of Malaysia young ginger (Zingiber officinale Roscoe). Molecules, 15(6), 4324-4333.

Guiné, R. P. F., Henrriques, F., \& Barroca, M. J. (2012). Mass transfer coefficients for the drying of pumpkin (Cucurbita moschata) and dried product quality. Food and Bioprocess Technology, 5(1), 176-183.

Hao, M., \& Beta, T. (2012). Development of Chinese steamed bread enriched in bioactive compounds from barley hull and flaxseed hull extracts. Food Chemistry, 133(4), 1320-1325.

Hoşgün, E. Z., \& Bozan, B. (2013). Keten Tohumu Yağının Süperkritik Akışkan Ekstraksiyon Kinetiğinin Difüzyon Kontrol Metodu İle Modellenmesi. Anadolu University of Sciences \& Technology-A: Applied Sciences \& Engineering, 14(1).

Johnsson, P., Kamal-Eldin, A., Lundgren, L. N., \& Åman, P. (2000). HPLC method for analysis of secoisolariciresinol diglucoside in flaxseeds. Journal of agricultural and food chemistry, 48(11), 5216-5219.

Kajla, P., Sharma, A., \& Sood, D. R. (2015). Flaxseed-a potential functional food source. Journal of food science and technology, 52(4), 1857-1871.

Kanakdande, D., Bhosale, R. And Singhal, R.S. 2007. Stability of cumin oleoresin microencapsulated in different combination of gum arabic, maltodextrin and modified starch. Carbohydrate Polymers, 67 (4): 536-541.

Küçüközet, A. O., \& Uslu, M. K. (2018). Cooking loss, tenderness, and sensory evaluation of chicken meat roasted after wrapping with edible films. Food Science and Technology International, 24(7), 576-584.

Maizura, M., Aminah, A., \& Wan Aida, W. M. (2011). Total phenolic content and antioxidant activity of kesum (Polygonum minus), ginger (Zingiber officinale) and turmeric (Curcuma longa) extract. International Food Research Journal, 18(2).

Mercier, S., Mondor, M., Villeneuve, S., Marcos, B., \& Moresoli, C. (2015). Assessment of the Oxidative Stability of FlaxseedEnriched Lasagna Using the R ancimat Method. Journal of food processing and preservation, 39(6), 1729-1734.

Milder, I. E., Arts, I. C., Venema, D. P., Lasaroms, J. J., Wähälä, K., \& Hollman, P. C. (2004). Optimization of a liquid chromatography - tandem mass spectrometry method for quantification of the plant lignans secoisolariciresinol, matairesinol, lariciresinol, and pinoresinol in foods. Journal of agricultural and food chemistry, 52(15), 4643-4651.

Montgomery, D. C. (2001). Design and analysis of experiments. John Wiley \& Sons. Inc., New York, 1997, $200-1$.

Nile, S. H., \& Park, S. W. (2015). Chromatographic analysis, antioxidant, anti-inflammatory, and xanthine oxidase inhibitory activities of ginger extracts and its reference compounds. Industrial Crops and Products, 70, 238-244.

Noguchi, C., \& Nikki, E. (2000). Phenolic antioxidants: A rationale for design and evaluation of novel antioxidant drugs for atherosclerosis. Free Radical Biology and Medicine, 28, 1538-1546.

Oboh, G., Akinyemi, A. J., \& Ademiluyi, A. O. (2012). Antioxidant and inhibitory effect of red ginger (Zingiber officinale var. Rubra) and white ginger (Zingiber officinale Roscoe) on Fe2+ induced lipid peroxidation in rat brain in vitro. Experimental and Toxicologic Pathology, 64(1-2), 31-36.

Ponce, A.G., Roura, S.I., Del Valle, C.E. And Moreira, M.R. 2008. Antimicrobial and antioxidant activities of edible coatings enriched with natural plant extracts: in vitro and in vivo studies. Postharvest biology and technology, 49 (2): 294-300.

Renouard, S., Hano, C., Corbin, C., Fliniaux, O., Lopez, T., Montguillon, J., ... \& Lainé, E. (2010). Cellulase-assisted release of secoisolariciresinol from extracts of flax (Linum usitatissimum) hulls and whole seeds. Food chemistry, $122(3), 679-687$.

Sarıtaş, N. (2018). Ceviz yeşil kabuğundan ultrases yardımıyla fenolik madde ekstraksiyonu, kinetik modellenmesi ve optimizasyonu (Master's thesis, Pamukkale Üniversitesi Fen Bilimleri Enstitüsü).

Scalbert, A., Johnson, I. T., \& Saltmarsh, M. (2005). Polyphenols: antioxidants and beyond. The American journal of clinical nutrition, 81(1), 215S-217S.

Sha1kh, J., Bhosale, R. And Singhal, R. 2006. Microencapsulation of black pepper oleoresin. Food chemistry, 94 (1): $105-110$.

Singleton, V. L., \& Rossi, J. A. (1965). Colorimetry of total phenolics with phosphomolybdic-phosphotungstic acid reagents. American journal of Enology and Viticulture, 16(3), 144-158.

Visioli, F., Caruso, D., Plasmati, E., Patelli, R., Mulinacci, N., Romani, A., Galli, G., Galli, C. 2001. Hydroxytyrosol, as a component of olive mill waste water, is dose-dependently absorbed and increases the antioxidant capacity of rat plasma. Free Radic. Res. 34:301-305.

Yeh, H. Y., Chuang, C. H., Chen, H. C., Wan, C. J., Chen, T. L., \& Lin, L. Y. (2014). Bioactive components analysis of two various gingers (Zingiber officinale Roscoe) and antioxidant effect of ginger extracts. LWT-Food Science and Technology, 55(1), 329-334.

Zancan, K. C., Marques, M. O., Petenate, A. J., \& Meireles, M. A. A. (2002). Extraction of ginger (Zingiber officinale Roscoe) oleoresin with $\mathrm{CO} 2$ and co-solvents: a study of the antioxidant action of the extracts. The Journal of supercritical fluids, 24(1), 5776.

Zhang, F., Yang, Y., Su, P., \& Guo, Z. (2009). Microwave-assisted extraction of rutin and quercetin from the stalks of Euonymus alatus (Thunb.) Sieb. Phytochemical analysis, 20(1), 33-37. 